\title{
MENINGKATKAN HASIL BELAJAR IPS SISWA MELALUI \\ PEMBELAJARAN KOOPERATIF STAD (STUDENT \\ TEAMS ACHIEVEMENT DIVISIONS) KELAS V SD ETIS LANDIA KEC.MEDAN HELVETIA
}

\author{
Herawaty Bukit \\ Surel: Herawaty.bukit@gmail.com
}

\begin{abstract}
ABSTRAK
Tujuan penelitian ini adalah untuk meningkatkan hasil belajar siswa melalui model pembelajaran kooperatif tipe STAD di kelas V SD Swasta Etis Landia T.A 2015/2016. Subjek penelitian adalah siswa kelas V SD berjumlah 27 orang. Teknik pengumpulan data berupa lembar observasi aktivitas siswa dan guru. Hasil penelitian menunjukkan pada pretes diperoleh nilai rata-rata 61,85 dari 27 siswa $(37,03 \%)$ atau 10 siswa yang tuntas. Pada siklus I diperoleh ratarata 69,62 dengan 17 orang siswa $(62,96 \%)$ sudah tuntas, dan pada siklus II diperoleh nilai rata-rata 79,62 dengan 24 orang siswa $(88,89 \%)$ sudah tuntas dan 3 orang siswa $(14,81 \%)$ belum tuntas belajar. Hasil observasi siswa siklus I $59,97 \%$ dan siklus II $87,5 \%$. Demikian pula hasil observasi guru siklus I $83.92 \%$ dan siklus II 94,64\%.
\end{abstract}

Kata Kunci : Hasil Belajar, IPS, Pembelajaran Kooperatif STAD

\section{PENDAHULUAN}

Pendidikan merupakan suatu upaya dalam mempersiapkan sumber daya manusia (human research) yang memiliki keterampilan dan keahlian sesuai tuntutan bangsa. Pendidikan memegang peranan penting dalam mencerdaskan kehidupan bangsa, oleh karena itu setiap individu yang terlibat dalam pendidikan dituntut berperan serta secara maksimal guna meningkatkan mutu tersebut.

Ilmu Pengetahuan Sosial (IPS) merupakan salah satu mata pelajaran dalam Kurikulum di SD/MI. Melalui mata pelajaran IPS, siswa diarahkan, dibimbing, dan dibantu untuk menjadi warga Negara Indonesia dan warga dunia yang demokratis. Hal ini merupakan tantangan berat karena masyarakat global selalu mengalami perubahan setiap saat. Untuk itulah, pengetahuan sosial dirancang unuk membangun dan merefleksikan kemampuan siswa dalam kehidupan bermasyarakat yang selalu berubah dan berkembang secara terus menerus.

Pembelajaran Ilmu Pengetahuan Sosial (IPS) tidak hanya menuntut siswa untuk memahami apa yang telah dipelajari, tetapi juga harus mampu memberikan contoh-contoh sosial yang nyata di lingkungan masyarakat seputar materi yang disampaikan.

Berdasarkan hasil observasi yang peneliti lakukan di SD Swasta Etis Landia Kec. Medan. Kurangnya sarana dan alat peraga yang mendukung proses pembelajaran IPS, sehingga membuat proses pembelajaran terpusat pada guru, dan siswa cenderung pasif. Situasi belajar mengajar yang kurang kondusif membuat siswa justru melakukan aktivitas yang tidak bermanfaat. Banyak diantara mereka yang ramai 
sendiri, menganggu teman, sekedar coret-coret buku, melamun bahkan adapula yang mengantuk. Guru kurang memberi motivasi kepada siswa untuk lebih bersemangat dalam mengikuti pembelajaran di kelas. Sehingga aktivitas belajar siswa rendah.

Penggunaan metode ceramah oleh guru membuat sebagian siswa merasa bosan mengikuti pembelajaran Ilmu Pengetahuan Sosial (IPS). Beberapa siswa mengaku kesusahan dalam memahami materi, terlebih-lebih Ilmu Pengetahuan Sosial (IPS) memuat banyak materi-materi hafalan. Kurang tepatnya model yang diterapkan guru dalam mengajar Ilmu Pengetahuan Sosial (IPS), maka sangat berpengaruh terhadap hasil belajar Ilmu Pengetahuan Sosial (IPS) siswa.

Berdasarkan latar belakang dan identifikasi masalah di atas, cukup banyak masalah yang perlu diteliti. Karena terbatasnya waktu, tenaga serta sarana yang tersedia, maka penulis membatasi permasalahan hanya mengetahui bagaimana hasil belajar siswa dengan menggunakan model kooperatif tipe STAD pada materi pelajaran Perjuangan Mempertahankan Kemerdekaan kelas V SD Swasta Etis Landia Kec. Medan Helvetia.

Berdasarkan rumusan masalah di atas, maka tujuan dilaksanakan penelitian ini adalah: Untuk mengetahui peningkatan hasil belajar IPS siswa pada materi pelajaran Perjuangan Mempertahankan Kemerdekaan dengan menggunakan mAd 1 _mb 1 : in n kooperatif tipe p-ISSN 2407-4934

e-ISSN 2355-1747
STAD (Student Teams Achievement Divisions) kelas V SD Swasta Etis Landia Kec. Medan Helvetia T.A 2015/2016.

Menurut Suyono (2014:9) "belajar adalah suatu proses untuk memperoleh pengetahuan, meningkatkan keterampilan, memperbaiki perilaku, sikap dan mengkokohkan kepribadian. Sedangkan menurut Agus (2010:2) "belajar adalah mengamati, membaca, meniru, mencoba sesuatu, mendengar dan mengikuti arah tertentu.

Menurut Winkel (dalam Purwanto 2011:45) mengatakan "hasil belajar merupakan perubahan yang mengakibatkan manusia berubah dalam sikap dan tingkah lakunya. Aspek perubahan itu mengacu kepada taksonomi tujuan pengajaran yang mencakup aspek kognitif, afektif, dan psikomotorik. Sedangkan menurut Purwanto (2011:54) "hasil belajar adalah perubahan perilaku yang terjadi setelah mengikuti proses belajar mengajar sesuai dengan tujuan pedidikan".

Menurut Nurulhayati (dalam Rusman 2012:203) mengatakan "pembelajaran kooperatif adalah strategi pembelajaran yang melibatkan partisipasi siswa dalam satu kelompok kecil untuk saling berinteraksi”.

Pembelajaran kooperatif menurut Sanjaya (2010:246), adalah kegiatan belajar siswa yang dilakukan dengan cara berkelompok. Model pembelajaran kelompok adalah rangkaian kegiatan belajar yang dilakukan oleh siswa dalam kelompok-kelompok tertentu untuk 
mencapai tujuan pembelajaran yang telah dirumuskan.

Berdasarkan uraian di atas, peneliti menyimpulkan bahwa pembelajaran kooperatif adalah pembelajaran yang mengutamakan kerjasama dan kebersamaan dalam menyelesaikan suatu permasalahan. Pembelajaran kooperatif sekaligus mengajarkan pada siswa tentang penyesuaian diri, tanggung jawab, dan saling menghargai satu sama lain. Pembelajaran kooperatif penting untuk diterapkan karena dengan cara berkelompok siswa dapat menyelesaikan permasalahan sekaligus belajar bermasyarakat.

Berdasarkan pendapat di atas maka peneliti dapat menyimpulkan bahwa model pembelajaran kooperatif STAD merupakan pendekatan Cooperative Learning yang menekankan pada aktivitas dan interaksi diantara 4-5 orang siswa untuk saling memotivasi dan saling membantu dalam menguasai materi pelajaran guna mencapai prestasi yang maksimal. Guru yang menggunakan STAD bertugas menyajikan pelajaran sedangkan siswa bekerja secara tim dan bertugas memastikan bahwa seluruh anggota tim telah menguasai materi yang diajarkan.

Tinggi rendahnya hasil belajar siswa dipengaruhi oleh beberapa faktor, yang salah satunya adalah guru. Disinilah dituntut kemampuan seorang guru untuk mampu memilih dan memanfaatkan model pembelajaran sebaik mungkin sehingga timbul hasil belajar yang lebih tinggi dari siswa. Model pembelajaran yang diupayakan untuk itu adalah model pembelajaran kooperatif tipe STAD dalam belajar serta menumbuhkan daya ingat yang kuat. Model pembelajaran STAD merupakan variasi pembelajaran kooperatif. Model ini digunakan untuk membuat suasana belajar lebih menyenangkan.

\section{METODE PENELITIAN}

Penelitian ini menggunakan penelitian tindakan kelas (Classroom Action Research). Tujuan dari Penelitian Tindakan Kelas adalah untuk memperbaiki sebagai persoalan nyata dan praktis dalam meningkatkan mutu pembelajaran di kelas yang dialami langsung dalam interaksi guru dengan siswa yang sedang belajar.

Tempat Penelitian Tindakan Kelas ini akan dilaksanakan di Jalan Gaperta Ujung Gg Berkat No 32 pada kelas V SD Swasta Etis Landia Kec. Medan Helvetia Kel.Tanjung Gusta pada mata pelajaran IPS tahun ajaran 2015/2016 selama 3 bulan (mulai kegiatan persiapan mengajar sampai pelaksanaan tindakan).

Objek dalam penelitian ini adalah kemampuan siswa terhadap materi noknk Peniaiahan Relanda di Herawaty Bukit: Meningkatkan Hasil ...

meningkatkan hasil belajar dengan menggunakan model kooperatif tipe STAD pada siswa kelas V SD.

Observasi p-ISSN 2407-4934 mengetahui kes e-ISSN 2355-1747 dengan rencana yang telah disusun dan guna mengetahui sejauh mana pelaksanaan tindakan dapat 
menghasilkan perubahan yang sesuai dengan yang dikehendaki. Observasi ini dilakukan untuk melihat apakah kondisi belajar siswa di kelas sudah terlaksana sesuai dengan program yang diberikan. Program yang dilaksanakan meliputi hasil belajar siswa dengan acuan lembar observasi dan tes.

Peneliti dengan guru kelas mendiskusikan hasil pengamatan selama kegiatan dan hasil tes yang telah diberikan. Setelah berakhirnya seluruh siklus, tindakan guru memberikan tes akhir berguna untuk memperbaiki masalah yang terdapat pada siklus I, dan mengetahui perubahan tingkat keberhasilan seluruh tindakan yang telah dilaksanakan dalam rangka meningkatkan hasil belajar siswa dengan menggunakan model pembelajaran kooperatif tipe STAD (Student Teams Achievement Divisions). Pada mata pelajaran IPS dalam materi pelajaran Perjuangan Mempertahankan Kemerdekaan di kelas V SD Etis Landia Kec. Medan Helvetia T.A 2015/2016.

Tes hasil belajar berupa post test dengan jumlah soal 20 soal, diberikan dalam bentuk objektif dengan lembaran test. Selanjutnya tes hasil belajar tersebut di analisis untuk perbaikan yang tujuannya adalah untuk meningkatkan hasil belajar

\section{p-ISSN 2407-4934 \\ e-ISSN 2355-1747}

\section{HASAN}

Berdasarkan hasil pretest, maka dapat diketahui bahwa tingkat ketuntasan hasil belajar siswa masih rendah. Oleh karena itu peneliti merencanakan alternatif dengan mempelajari kesulitan-kesulitan yang dihadapi siswa dengan menerapkan model pembelajaran Student Team Achievement Divisions (STAD) sebagai upaya yang dilakukan peneliti untuk memperbaiki proses belajar mengajar yang dilaksanakan adapun upaya yang dilakukan peneliti yaitu: a) Menyiapkan Rencana Pelaksanan Pembelajaran (RPP), b) Mempersiapkan bahan/model dan materi yang akan diajarkan pada materi Perjuangan Mempertahankan Kemerdekaan, c) Membuat soal-soal tugas yang akan diberikan pada masing-masing siswa berdasarkan kompetensi dasar yang dipelajari, d) Membuat lembar observasi untuk melihat bagaimana perkembangan peneliti dalam penyampaian materi kepada peserta didik didalam kelas, e) Menyusun tes untuk mengukur hasil belajar siswa selama tindakan penelitian diterapkan yaitu soal siklus post test siklus I.

Pembahasan hasil penelitian ini didasarkan pada hasil pengamatan dengan hasil refleksi pengamatan pada tindakan siklus I dan siklus II. Dari refleksi pengamatan siklus I diperoleh temuan sebagai berikut:

1. Sebelum memberikan pengajaran dengan menggunakan model STA $\mathrm{D}$, terlebih dahulu siswa diberikan pretes untuk mengetahui tingkat $p$ enguasaan siswa pada pelajaran $\mathrm{m}$ ateri pokok Perjuangan Memperta hankan Kemerdekaan. Dari hasil p retes diketahui hanya 10 siswa (37 ,03\%) yang dinyatakan tuntas bela 
jar dan 17 siswa (62,96\%) lagi din yatakan tidak tuntas. Dari hasil ter sebut diketahui tingkat ketuntasan belajar secara klasikal sebesar 37, $03 \%$ yang berarti belum memenuh i syarat ketuntasan belajar.

Dari hasil tersebut beberapa ya ng dapat dianalisis adalah sebagai berikut:

a. Siswa belum memiliki tingkat penguasaan yang memadai ten tang materi pokok Perjuangan Mempertahankan Kemerdekaa $\mathrm{n}$

b. Siswa masih belum mampu $\mathrm{m}$ enjawab soal-soal yang diberik an.

2. Dari hasil pretes peneliti mengada kan upaya perbaikan dengan meng adakan kegiatan belajar mengguna kan metode resitasi yang dilakuka n pada siklus I. Dari hasil siklus I t ersebut terlihat adanya peningkata $\mathrm{n}$ ketuntasan belajar siswa dimana ada 17 siswa $(62,96 \%)$ yang dinya takan tuntas dan 10 siswa $(37,03 \%$ ) masih dinyatakan tidak tuntas be lajar, dari hasil tersebut diketahui bahwa ketuntasan belajar klasikal adalah sebesar $62,96 \%$ yang juga masih tergolong belum tuntas bela jar.

3. Dari hasil siklus I tersebut penelit i melakukan perbaikan strategi pem belajaran dengan mengoptimalkan aktivitas belajar siswa dan memoti vasi siswa untuk fokus dan serius dalam mengikuti kegiatan pembel ajaran terutama dalam pembelajar an IPS materi pokok Perjuangan M empertahankan Kemerdekaan den gan menggunakan model STAD.
Dari hasil tersebut diketahui bahw a pada siklus II tersebut dari jumla h 27 orang dinyatakan 24 siswa (8 $8,89 \%$ ) dinyatakan tuntas belajar $\mathrm{d}$ an 3 siswa $(14,81 \%)$ lagi belum tu ntas belajar dikarenakan 4 orang a nak tersebut rata-rata pengetahuan nya masih di bawah rata-rata. Dari hasil tersebut diketahui bahwa pad a siklus II tersebut dari jumlah 27 siswa sudah 24 siswa dinyatakan $\mathrm{t}$ untas belajar dan 3 siswa belum tu ntas belajar.

4. Berdasarkan hasil belajar dari pret es, siklus I dan siklus II diketahui bahwa penggunaan Model STAD melalui alur PTK dapat meningkat kan hasil belajar siswa pada pelaja ran IPS materi pokok Perjuagan M empertahankan Kemerdekaan. Ad anya peningkatan hasil belajar sis wa tersebut terlihat dari peningkat an penguasaan materi siswa yang $\mathrm{s}$ Herawaty Bukit: Meningkatkan Hasil ...

Dalam penelitian ini setiap akhir pertemuan diadakan test menggunakan soal pilihan berganda di siklus 1 dan si p-ISSN 2407-4934 digunakan untuk e-ISSN 2355-1747 besar hasil belajar siswa yang telah dicapai setelah mengikuti pembelajaran dengan menggunakan model Student Teams Achievement Division. Penilaian dalam penelitian ini meliputi dua hal yaitu: penilaian dari hasil belajar yang diperoleh dari test siswa dan penilaian dari hasil observasi terhadap guru dan siswa dalam proses pembelajaran. 


\section{KESIMPULAN}

Berdasarkan hasil analisis data dari penelitian yang dilaksanakan, dapat disimpulkan bahwa melalui model pembelajaran kooperatif tipe STAD dapat meningkatkan hasil belajar IPS siswa kelas V SD Swasta Etis Landia yang dapat dilihat pada:

1. Selama proses pembelajaran kooperatif tipe STAD, terjadi peningkatan hasil belajar siswa yang terlihat dari hasil belajar siswa antara skor dasar dengan hasil belajar siswa pada post tes I dengan rata-rata hasil belajar siswa 69,6 sedangkan rata-rata hasil belajar siswa pada post tes siklus II adalah 76,6.

2. Berdasarkan skor hasil belajar untuk setiap indikator terdapat peningkatan jumlah siswa yang mencapai KKM dari 62,96\% pada siklus I, sedangkan pada siklus II menjadi $88,89 \%$ siswa yang mencapai KKM. Dengan demikian dapat dikatakan melalui model pembelajaran kooperatif p-ISSN 2407-4934

e-ISSN 2355-1747 it meningkatkan iswa.

ग. Nilal rata-rata yang diperoleh siswa pada siklus I sebesar 69,62 dari 27 siswa, dimana 17 orang siswa $(62,96 \%)$ telah tuntas dalam belajar sedangkan 10 orang siswa $(37,03 \%)$ belum tuntas dalam belajar.

4. Kemudian pada siklus II terjadi peningkatan nilai rata-rata menjadi 79,62 dari 27 orang siswa dimana 24 orang siswa $(88,89 \%)$ siswa telah mengalami ketuntasan belajar, sedangkan 3 orang siswa lagi $(14,81 \%)$ belum berhasil.

Adapun saran yang ingin disampaikan peneliti adalah:

1. Dalam proses belajar mengajar guru diharapkan dapat menggunakan model pembelajaran kooperatif tipe STAD khususnya pada mata pelajaran IPS karena model ini dapat meningkatkan hasil belajar siswa.

2. Bagi siswa dapat dijadikan bahan yang dapat bermanfaat dalam meningkatkan hasil belajar IPS karena pembelajarannya bersifat aktif.

3. Bagi Kepala Sekolah hendaknya dapat melakukan pengawasan mengenai model pembelajaran yang digunakan oleh guru dalam rangka lebih meningkatkan kinerja guru.

\section{DAFTAR RUJUKAN}

Arikunto,Suharsimi. 2013. Prosedur Penelitian. Jakarta: Rineka Cipta.

Hartono Rudi.2013. Ragam Model Mengajar Yang Mudah Diterima Murid. Yogyakarta: DIVA Press.

Istarani. 2012. 58 Model Pembelajaran Inovatif. Medan: Media Persada.

Sanjaya, Wina. 2011. Strategi Pembelajaran. Jakarta: 
ESJ VOLUME 5, NO. 1, JUNI 2016

Slameto. 2010. Belajar dan FaktorFaktor Yang Mempengaruhi. Jakarta: Rineka Cipta.

Sudjana, Nana. 2010. Dasar-dasar Proses Belajar Mengajar. Bandung: Sinar Baru Algesindo. riyono, Agus. 2010. Cooperative Learning. Yogyakarta: Pustaka Belajar.

Trianto. 2011. Mendesain Model Pembelajaran InovatifProgresif. Jakarta: Kencana.

Yusnadi. 2014. Filsafat Pendidikan. Medan: UNIMED PRESS. 